\title{
PEMBELAJARAN UNTUK MENGEMBANGKAN KEMAMPUAN PENALARAN INFERENSIAL STATISTIS
}

\author{
Laila Hayati \\ Dosen Program Studi Pendidikan Matematika FKIP, Universitas Mataram \\ Email : laila.hayati@student.upi.edu
}

\begin{abstract}
ABSTRAK
Artikel ini membahas tentang pembelajaran yang dapat digunakan untuk mengembangkan kemampuan penalaran inferensial statistis. Tujuan kognitif pembelajaran Statistika adalah untuk mengembangkan kemampuan literasi, penalaran, dan berpikir statistis. Salah satu tujuan dalam penalaran statistis adalah mengembangkan kemampuan penalaran inferensial. Model pembelajaran yang dapat digunakan untuk mengembangkan kemampuan penalaran inferensial statistis adalah model Statistical Reasoning Learning Environment (SRLE) yang didasarkan pada teori belajar konstruktivisme. Analisis didasarkan pada: 1) definisi inferensi statistis; 2) definisi penalaran inferensial informal dan formal; 3) kerangka kerja penalaran inferensial informal; 5) model pembelajaran SRLE; dan 6) penelitian terkait penalaran inferensial statistis.
\end{abstract}

Kata-kata kunci: inferensi statistis, penalaran inferensial informal, penalaran inferensial formal, model pembelajaran SRLE

\section{Pendahuluan}

Membuat inferensi merupakan bagian tak terpisahkan dari kehidupan sehari-hari maupun dalam penelitian ilmiah. Dalam buku Moore, McCabe, \& Craig (2009), tujuan inferensi statistis adalah untuk menarik kesimpulan tentang populasi atau prosesnya berdasarkan data sampel.

Pemahaman inferensi statistis penting dalam penelitian ilmiah karena konsep dan proses dalam inferensi statistis digunakan dalam studi empiris (Sotos, Vanhoof, Van den Noortgate \& Onghena, 2007). Pratt \& Ainley (Weinberg, Wiesner, \& Pfaff, 2010) juga mengemukakan hal yang sama, bahwa inferensi adalah bidang yang merupakan fondasi dalam Statistika. Selain itu, mahasiswa dituntut harus memahami ide dasar dari inferensi statistis dan merupakan tujuan pembelajaran dalam mata kuliah Pengantar Statistika (American Statistical Association, 2010).

Forum Internasional untuk Penelitian pada Literasi, Penalaran, dan Berpikir Statistis yang ke lima (International Forum for Research on Statistical Reasoning, Thinking, and Literacy-SRTL5) mengambil tema berkaitan dengan pemahaman inferensi statistis informal dari tingkat dasar sampai tingkat atas. Forum SRTL selanjutnya terus fokus pada inferensi statistis informal, misalnya SRTL 6 fokus pada sampel dan sampling, SRTL 7 fokus pada ketidakpastian, dan SRTL 8 fokus pada model (Makar \&
Rubin, 2009). Hal ini menunjukkan pentingnya pemahaman inferensi statistis.

Untuk mengajarkan inferensi statistis, seperti uji hipotesis dan interval kepercayaan, Garfield \& Ben-Zvi (2008), menyarankan bahwa ide-ide dari inferensi informal seharusnya diperkenalkan di awal perkuliahan. Hal ini dapat membantu mahasiswa yang bingung dengan ide-ide, prosedur, dan bahasa formal ketika akhirnya mencapai studi formal dari topik inferensi. Ketika ide-ide inferensi formal akhirnya diperkenalkan, mahasiswa tidak fokus pada perhitungan dan rumus, tetapi fokus pada ideide dan makna dari hipotesis nol dan alternatif, ide nilai $p$, atau tipe error.

Inferensi statistis informal dipelajari sebagai jembatan dalam mempelajari inferensi statistis formal, dengan kemampuan statistika deskriptif yang memadai. Dalam inferensi statistis informal, mahasiswa menarik kesimpulan tentang populasi berdasarkan data tanpa membuat interval kepercayaan atau melakukan uji hipotesis. Sebaliknya, inferensi statistis formal melibatkan uji hipotesis atau interval kepercayaan dengan data dari sampel, untuk menarik kesimpulan tentang populasi. Sebuah pemahaman menyeluruh tentang konsep dasar dan bagaimana menggunakannya diperlukan untuk membuat keputusan dengan analisis data yang sesuai.

Pemahaman yang baik dalam inferensi statistis, diharapkan dapat menunjang kemampuan penalaran inferensial 
statistis mahasiswa. Makar mengemukakan bahwa proses penalaran yang mengarah pada pembuatan inferensi statistis secara informal disebut penalaran inferensi statistis informal (Ben-Zvi \& Aridor-Berger, 2012). Jadi, dalam penalaran inferensial informal, mahasiswa merumuskan generalisasi (misalnya kesimpulan, prediksi) dari sampel acak data menggunakan berbagai alat statistik, dengan memperhatikan fakta-fakta yang ada dan konsep ketidakpastian, secara informal atau tanpa menggunakan uji hipotesis dan interval kepercayaan. Dengan bernalar secara informal, mahasiswa tidak perlu terikat dengan aturan-aturan dalam uji hipotesis maupun interval kepercayaan, sehingga dapat mengeksplor kemampuan mahasiswa lebih dalam dan menghasilkan jawaban yang bervariasi.

Setelah mahasiswa memiliki kemampuan penalaran inferensial informal yang baik, diharapkan dapat mempermudah dalam mempelajari inferensi statistis formal. Pemahaman konsep yang baik dalam inferensi statistis formal diharapkan dapat menunjang kemampuan penalaran inferensial formal mahasiswa.

Untuk dapat menumbuhkan kemampuan penalaran inferensial statistis tentunya dibutuhkan lingkungan pembelajaran yang kondusif dan memiliki setting pembelajaran yang menunjang mahasiswa untuk berkembang. Garfield \& Ben-Zvi (2009), menyarankan pendekatan pembelajaran untuk mengembangkan penalaran statistis, yaitu Statistical Reasoning Learning Environment (SRLE). SRLE

dibangun atas dasar teori belajar konstruktivisme. Peranan mahasiswa dalam setting konstruktivisme, adalah student centered. Mahasiswa aktif memanfaatkan pengetahuan yang sudah dimiliki untuk membentuk pengetahuan yang baru menurut mahasiswa, bisa benar atau salah. Peranan dosen, sebagai fasilitator untuk meluruskan konsep yang salah. Mahasiswa wajib mengemukakan pendapatnya sesuai level berpikirnya, atau dosen membentuk kelompok, dan mahasiswa belajar dari mahasiswa lain dengan setting kelompok untuk saling bertukar informasi dan mencari pemahaman bersama. Mahasiswa harus proaktif terlibat dan dosen memfasilitasi supaya tidak terhambat dalam pembentukan pengetahuan baru.

SRLE adalah sebuah kelas statistika yang efektif dan positif untuk mengembangkan pemahaman yang mendalam dan bermakna berkaitan dengan statistika dan membantu mahasiswa mengembangkan kemampuan berpikir dan bernalar secara statistis. Pendekatan ini disebut lingkungan belajar karena merupakan kombinasi interaktif bahan teks, kegiatan kelas, dan budaya, diskusi, teknologi, pendekatan pengajaran, dan penilaian.

Pendekatan SRLE didasarkan pada enam prinsip desain instruksional oleh Cobb dan McClain (Garfield \& Ben-Zvi, 2009), yaitu:

1. Fokus pada pengembangan konten statistika.

2. Menggunakan data real.

3. Menggunakan aktivitas kelas untuk mendukung pengembangan penalaran siswa.

4. Mengintegrasikan penggunaan alat-alat teknologi mengeksplorasi dan menganalisa data, dan mengembangkan penalaran statistik mereka.

5. Meningkatkan percakapan kelas, pertukaran yang berfokus pada ideide statistik.

6. Menggunakan penilaian alternatif.

Enam rekomendasi tersebut, digunakan untuk dapat mencapai tujuan pembelajaran dalam Pengantar Statistika. Atas dasar itu, SRLE dirasa dapat diterapkan dalam pembelajaran untuk mengembangkan kemampuan penalaran inferensial, baik informal maupun formal.

\section{Inferensi Statistis}

Menurut Collins (Garfield \& Ben-Zvi, 2008), inferensi statistis secara formal didefinisikan sebagai teori, metode, dan praktek dari bentuk penilaian tentang parameter populasi, biasanya atas dasar pengambilan sampel secara acak. Selanjutnya, Makar \& Rubin (2009) mengemukakan, inferensi statistis dalam arti luas adalah sebagai hasil dan proses bernalar menciptakan atau menguji generalisasi probabilistik dari data.

Moore et al. (2009: 354) mengatakan bahwa: "The purpose of statistical inference is to draw conclusions from data. Formal inference emphasizes substantiating our conclusions by probability calculations. Hal ini menjelaskan bahwa inferensi statistis bertujuan untuk menarik kesimpulan dari data tentang populasi, dengan mempertimbangkan variasi dan probabilitas.

Garfield \& Ben-Zvi (2008) mengkategorikan topik inferensi statistis menjadi dua yaitu estimasi parameter dan uji 
hipotesis. Untuk membedakan kedua bagian ini diberikan contoh (Walpole \& Myers, 1995):

1. Seorang pengusaha yang hendak memasarkan produksi barunya mungkin ingin menduga proporsi sesungguhnya calon produksi pembelinya dengan menanyakan pendapat sampel acak ukuran 100 calon pembeli. Proporsi calon pembeli yang mau membeli barangnya dalam sampel dapat dipakai sebagai dugaan proporsi calon pembeli sesungguhnya dalam populasi. Pengetahuan tentang distribusi sampel proporsi memungkinkan kita menentukan derajat ketepatan dugaan tersebut. Masalah ini merupakan contoh estimasi.

2. Seorang ibu ingin menentukan apakah sabun cuci Rinso mencuci lebih unggul daripada So Klin. Dia mungkin menghipotesiskan bahwa Rinso lebih baik daripada So Klin, dan setelah mengadakan pengujian secukupnya, si ibu menerima atau menolak hipotesis. Dalam contoh tersebut, parameter tidak diduga, tapi ingin mendapat keputusan yang benar mengenai hipotesis yang ditetapkan sebelumnya. Masalah ini merupakan uji hipotesis.

Inferensi statistis mengintegrasikan banyak ide-ide penting dalam statistika, seperti representasi data, ukuran pusat dan variasi, distribusi normal, dan sampling. Memperkenalkan dan meninjau materi ini sejak dini bisa memberikan siswa peluang untuk membangun kerangka konseptual yang diperlukan untuk mendukung penalaran inferensial. Sotos et al. (2007), mengungkapkan bahwa pemahaman yang kuat tentang inferensi statistis sangat penting untuk merancang dan menafsirkan hasil empiris dalam berbagai disiplin ilmu.

Inferensi statistis digunakan sebagai istilah untuk domain konten yang terdiri dari konsep-konsep dan ide-ide yang berkaitan dengan inferensi statistis. Yang termasuk dalam inferensi statistis adalah inferensi statistis informal (misalnya distribusi sampling) dan inferensi statistis formal (misalnya uji hipotesis)

\section{Penalaran Inferensial Informal dan Formal}

Pfannkuch (2006: 1), mendefinisikan penalaran inferensial informal sebagai "interconnected to reasoning from distribution, reasoning with measures of centre, and sampling reasoning within an empirical enquiry cycle". Dari kalimat tersebut, dapat diinterpretasikan bahwa penalaran inferensial informal saling berkaitan dengan penalaran yang lain seperti penalaran tentang distribusi, penalaran tentang ringkasan statistis (pemusatan, penyebaran, letak), dan penalaran tentang sampling.

Makar dan Rubin (2009: 82-83) mengemukakan bahwa "Informal inferential reasoning has shown some promise in developing students'deeper understanding of statistical processes. Informal inferential reasoning in statistics to be the process of making probabilistic generalizations from (evidenced with) data that extend beyond the data collected. Kalimat tersebut dapat diinterpretasikan bahwa dalam penalaran inferensial informal membutuhkan pemahaman siswa yang mendalam tentang proses statistika. Proses ini berkaitan dengan membuat generalisasi dari data.

Definisi yang lengkap mengenai penalaran inferensial informal dijelaskan oleh Zieffler, Garfield, Delmas, \& Reading (2008). Mereka mendefinisikan penalaran inferensial informal dengan menjelaskan masing-masing bagian yang mendukungnya, yaitu pengetahuan informal, penalaran informal, dan penalaran inferensial informal.

a. Pengetahuan Informal

Berikut beberapa penjelasan tentang bagaimana pengetahuan informal yang digunakan dalam pembelajaran formal (Zieffler, et al, 2008):

1. Pengetahuan informal dapat terdiri dari berbagai jenis pemahaman yang siswa bawa ke tugas belajar yang baru, dan dapat menggabungkan pengetahuan berdasarkan pengalaman dunia nyata dengan pengetahuan yang diperoleh dari pembelajaran sebelumnya;

2. Pengetahuan informal dapat menjadi titik awal yang penting untuk membangun pengetahuan formal, dan harus dipertimbangkan dalam merancang kurikulum;

3. Pembelajaran dapat dirancang untuk membantu siswa membangun tipe tertentu dari pengetahuan informal yang diperlukan untuk pembelajaran yang mungkin memerlukan pengetahuan formal konsep tertentu;

4. Pembelajaran berbasis kegiatan yang memerlukan interaksi sosial dan negosiasi makna dapat memfasilitasi pengembangan pengetahuan informal. 
Ulasan tersebut menunjukkan bahwa mengembangkan pengetahuan informal siswa dapat memudahkan transisi siswa untuk memahami ide formal inferensi.

b. Penalaran Informal Voss, Perkins, \& Segal (Zieffler et al. 2008) mendefinisikan penalaran informal merupakan salah satu jenis penalaran yang terjadi dalam situasi non-deduktif/ induktif. Hal ini berarti bahwa penalaran informal dimulai dengan hal-hal khusus hingga sampai pada generalisasi. Penalaran informal menjadi bagian penting dari penalaran inferensial informal karena peran bukti dan argumentasi dalam membuat prediksi dan keputusan statistis.

c. Penalaran Inferensial Informal

Penalaran inferensial informal saling berhubungan dengan penalaran tentang distribusi, ukuran pemusatan, variabilitas, dan sampling. Zieffler et al. (2008) menyimpulkan penalaran inferensial informal adalah proses yang meliputi:

1. Penalaran tentang kemungkinan karakteristik populasi (misalnya bentuk, pusat) berdasarkan sampel data;

2. Penalaran tentang kemungkinan perbedaan antara dua populasi berdasarkan perbedaan yang diamati antara dua sampel data (yaitu, perbedaan disebabkan oleh pengaruh perlakuan, bukan karena kebetulan);

3. Penalaran tentang kemungkinan sampel data tertentu memberikan harapan atau klaim tertentu.

Dari kedua pendapat tersebut dapat disimpulkan bahwa penalaran inferensial informal adalah cara siswa bernalar menggunakan pengetahuan pengetahuan informal atau ide-ide yang saling berkaitan (misalnya penalaran tentang distribusi, ringkasan statistis (pemusatan, penyebaran, letak), dan sampling) untuk membuat kesimpulan tentang populasi berdasarkan sampel yang diamati. Sebaliknya penalaran inferensial formal melibatkan konstruksi teoritis nilai-p dan interval kepercayaan.

\section{Kerangka kerja Penalaran Inferensial Informal \\ Ada beberapa kerangka kerja} penalaran inferensial informal, antara lain yang dikemukakan oleh Zieffler et al. (2008) dan Makar \& Rubin (2009).

Kerangka kerja penalaran inferensial informal yang dibuat oleh Zieffler et al. (2008) adalah:

1. Membuat penilaian, klaim, atau prediksi tentang populasi berdasarkan sampel, tetapi tidak menggunakan prosedur dan metode statistis formal (misalnya nilai $p$, uji t);

2. Menggambarkan, memanfaatkan dan mengintegrasikan pengetahuan sebelumnya (misalnya pengetahuan formal tentang konsep dasar, seperti distribusi atau rata-rata, pengetahuan informal tentang inferensi seperti mengakui bahwa sampel mengejutkan mengingat klaim tertentu, menggunakan bahasa probabilitas);

3. Mengartikulasikan argumen berbasis bukti untuk penilaian, klaim, atau prediksi tentang populasi berdasarkan sampel.

Jadi penalaran inferensial informal adalah sebagai proses untuk membuat inferensi yang tidak memanfaatkan metode formal dari inferensi statistis.

Selain itu, Zieffler et al. (2008) mengemukakan jenis tugas yang digunakan untuk mengembangkan Penalaran Inferensial Informal. Jenis tugas tersebut dapat dilihat dalam tabel 1 berikut: 
Tabel 1: Spesifikasi jenis tugas yang menggabungkan tiga komponen Penalaran Inferensial Informal

\begin{tabular}{|c|c|c|c|}
\hline \multirow[t]{2}{*}{ Jenis Tugas } & \multicolumn{3}{|c|}{ Komponen Penalaran Inferensial Informal } \\
\hline & $\begin{array}{l}\text { Membuat } \\
\text { penilaian } \\
\text { prediksi }\end{array}$ & $\begin{array}{l}\text { Menggunakan atau } \\
\text { mengintegrasikan } \\
\text { pengetahuan } \\
\text { sebelumnya }\end{array}$ & $\begin{array}{l}\text { Mengartikulasikan } \\
\text { argumen berbasis } \\
\text { bukti }\end{array}$ \\
\hline $\begin{array}{l}\text { Estimasi dan } \\
\text { menggambar } \\
\text { grafik populasi }\end{array}$ & $\begin{array}{l}\text { Memprediksi } \\
\text { karakteristik suatu } \\
\text { populasi (bentuk, } \\
\text { pusat, } \\
\text { peenyebaran) yang } \\
\text { direpresentasikan } \\
\text { dalam grafik yang } \\
\text { dibangun siswa }\end{array}$ & $\begin{array}{l}\text { Membawa intuisi atau } \\
\text { pengetahuan yang } \\
\text { dipelajari sebelumnya } \\
\text { dan bahasa untuk } \\
\text { memprediksi } \\
\text { karakteristik suatu } \\
\text { populasi (misalnya, ide } \\
\text { bentuk, kata-kata seperti } \\
\text { skewed/ miring) }\end{array}$ & $\begin{array}{l}\text { Membutuhkan } \\
\text { penjelasan tentang } \\
\text { bagaimana } \\
\text { karakteristik grafik } \\
\text { populasi dipilih }\end{array}$ \\
\hline $\begin{array}{l}\text { Membandingk } \\
\text { an dua data } \\
\text { sampel }\end{array}$ & $\begin{array}{l}\text { Menilai apakah ada } \\
\text { perbedaan antara } \\
\text { dua populasi, } \\
\text { berdasarkan } \\
\text { persamaan atau } \\
\text { perbedaan dalam } \\
\text { sampel data; }\end{array}$ & $\begin{array}{l}\text { Membawa intuisi atau } \\
\text { pengetahuan yang } \\
\text { dipelajari sebelumnya } \\
\text { dan bahasa untuk untuk } \\
\text { membandingkan } \\
\text { dua sampel data } \\
\text { (misalnya, antara dan } \\
\text { antar kelompok variasi) }\end{array}$ & $\begin{array}{lr}\text { Membutuhkan } & \\
\text { penjelasan } & \\
\text { mengapa siswa } & \\
\text { menentukan } & \text { ada } \\
\text { atau tidak } & \text { ada } \\
\text { perbedaan dalam } & \\
\text { dua populasi } & \end{array}$ \\
\hline $\begin{array}{l}\text { Menilai antara } \\
\text { dua model }\end{array}$ & $\begin{array}{l}\text { Menilai apakah } \\
\text { data sampel } \\
\text { memberikan } \\
\text { dukungan lebih } \\
\text { bagi satu model } \\
\text { dari yang lain }\end{array}$ & $\begin{array}{l}\text { Membawa intuisi atau } \\
\text { pengetahuan yang } \\
\text { dipelajari sebelumnya } \\
\text { dan bahasa untuk untuk } \\
\text { menilai antara dua model } \\
\text { yang saling bersaing } \\
\text { (misalnya, variabilitas } \\
\text { sampel, } \\
\text { kesempatan) variasi }\end{array}$ & $\begin{array}{l}\text { Membutuhkan } \\
\text { penjelasan } \\
\text { mengapa siswa } \\
\text { memilih satu model } \\
\text { atas model bersaing }\end{array}$ \\
\hline
\end{tabular}

Makar \& Rubin (2009) membuat kerangka kerja inferensi statistis informal dan penalaran inferensial dalam konteks investigasi statistik. Tiga prinsip penalaran Inferensi Statistis Informal tersebut adalah:

1. Generalisasi, termasuk prediksi, estimasi parameter, dan kesimpulan, yang melampaui gambaran data yang diberikan;

2. Menggunakan data sebagai bukti dari generalisasi;

3. Menggunakan bahasa probabilitas dalam menggambarkan generalisasi, termasuk referensi informal untuk tingkat kepastian tentang kesimpulan yang diambil.

Kedua kerangka kerja tersebut digunakan untuk mendukung penalaran inferensial informal dan mengevaluasi kemampuan mahasiswa terkait penalaran inferensial secara informal.

\section{Pendekatan Pembelajaran Statistical Reasoning Learning Environment (SRLE)}

Delmas (Garfield \& Ben-Zvi, 2008) berpendapat bahwa penalaran statistis harus menjadi tujuan eksplisit pembelajaran. Salah satu cara untuk melakukannya adalah belajar dalam kegiatan fisik dan visual untuk mengembangkan pemahaman konsep abstrak dan penalaran. Pemahaman tersebut mencakup tentang bagaimana data yang dihasilkan, bagaimana dan mengapa ringkasan statistik yang sesuai dipilih, dan bagaimana kesimpulan yang bisa ditarik.

Alasan utama untuk mengubah pendekatan yang teacher-centered menjadi student-centered, adalah bahwa pendekatan ini lebih efektif membantu siswa membangun pemahaman yang lebih dalam dan mampu mentransfer apa yang telah mereka pelajari dengan teman di kelas atau dalam dunia nyata. 
Implikasi dari teori-teori belajar saat ini adalah bahwa pembelajaran yang baik terdiri dari merancang lingkungan belajar yang merangsang siswa untuk membangun pengetahuan (Garfield \& Ben-Zvi, 2008). Hal ini melibatkan kegiatan yang memberikan siswa banyak kesempatan untuk berpikir, bernalar, dan bertukar pikiran dengan teman mereka. Untuk dapat mencapai tujuan pembelajaran tersebut, ditawarkan enam rekomendasi bagaimana mengajar Pengantar Statistika sebagai berikut:

1. Menekankan literasi statistis dan mengembangkan berpikir statistis;

2. Menggunakan data real;

3. Menekankan pemahaman konseptual, daripada pengetahuan belaka atau prosedur;

4. Menekankan pembelajaran aktif dalam pembelajaran;

5. Menggunakan teknologi untuk mengembangkan pemahaman konseptual dan menganalisis data;

6. Menggunakan asesmen untuk memperbaiki dan mengevaluasi pembelajaran siswa.

Model pembelajaran yang didasarkan atas prinsip-prinsip di atas adalah model pembelajaran Statistical Reasoning Learning Environment (SRLE), yaitu sebuah kelas statistik yang efektif dan positif sebagai lingkungan belajar untuk mengembangkan pemahaman siswa secara mendalam dan bermakna, dan membantu siswa untuk mengembangkan kemampuan mereka untuk berpikir dan bernalar secara statistis. Model pembelajaran SRLE dibangun atas dasar teori belajar konstruktivisme, bahwa siswa membangun (mengkonstruk) pengetahuan mereka sendiri, bukan dengan menerima pengetahuan.

Zvi, 2008):

Prinsip-prinsip SRLE (Garfield \& Ben-

1. Fokus pada pengembangan ide-ide statistik utama daripada menyajikan seperangkat alat dan prosedur; Ide-ide statistik utama yang harus dikuasai siswa, adalah: data, distribusi, variabilitas, pusat, model statistis, sifat acak, kovariasi, sampling, dan inferensi statistis.

2. Menggunakan seperangkat data riil dan memotivasi siswa untuk melibatkan para siswa dalam pembuatan dan pengujian konjektur;
Data adalah jantung pekerjaan statistik, dan data harus menjadi fokus dalam belajar statistik juga. Siswa perlu mempertimbangkan metode pengumpulan data, dan bagaimana metode yang dipilih mempengaruhi kualitas data dan jenis analisis yang sesuai. Kumpulan data yang menarik akan memotivasi siswa untuk membuat konjektur tentang data sebelum menganalisisnya. Menggunakan data riil akan menarik minat siswa, juga sebagai cara untuk melibatkan siswa dalam berpikir tentang data dan konsep statistik yang relevan, membantu siswa belajar merumuskan pertanyaan yang baik dan menggunakan data untuk menjawab pertanyaan berdasarkan bagaimana dan mengapa data dihasilkan.

3. Menggunakan kegiatan kelas untuk mendukung pengembangan penalaran siswa;

Bagian penting dari SRLE adalah penggunaan kegiatan yang dirancang dengan hati-hati yang mendorong siswa belajar melalui kolaborasi, interaksi, diskusi, data, dan masalah yag menarik. Belajar aktif memungkinkan siswa untuk memecahkan masalah, menjawab pertanyaan, merumuskan pertanyaan mereka sendiri, mendiskusikan, menjelaskan, atau debat selama dalam kelas. Jadi siswa terlibat dalam menemukan, membangun, dan memahami ide-ide penting statistik.

4. Mengintegrasikan penggunaan alat-alat teknologi yang tepat yang memungkinkan siswa menguji dugaan mereka, mengeksplorasi dan menganalisa data, dan mengembangkan penalaran statistis mereka;

Dengan menggunakan komputer atau kalkulator, siswa tidak lagi menghabiskan waktu melakukan perhitungan. Setelah memahami bagaimana rumus bekerja, mereka dapat mengotomatisasi prosedur ini menggunakan teknologi. $\mathrm{Hal}$ ini memungkinkan siswa untuk fokus pada tugas-tugas yang lebih penting belajar bagaimana metode analitik yang tepat dan bagaimana menginterpretasikan hasil. Teknologi juga memungkinkan siswa untuk mengembangkan pemahaman tentang konsep abstrak melalui simulasi, keterkaitan antara konsep-konsep, dan membantu siswa memvisualisasikan konsep. Teknologi harus digunakan untuk menganalisis 
data, yang memungkinkan siswa untuk fokus pada interpretasi hasil.

5. Meningkatkan wacana dalam kelas yang meliputi argumen statistis dan pertukaran berkelanjutan mengenai ide-ide statistik yang signifikan;

Dalam kelas, mendorong siswa untuk aktif dan berargumen, siswa terlibat dalam diskusi tentang masalah statistik yang signifikan. Panduan untuk guru: 1). Menggunakan pertanyaan yang baik yang mendorong siswa untuk berpikir dan tidak selalu memiliki satu jawaban yang benar; 2). Mengharuskan siswa untuk menjelaskan alasan mereka dan menanyakan siswa lain apakah mereka setuju atau tidak dengan pendapat temannya, dan menjelaskan mengapa; 3). Menciptakan situasi dan kondisi kelas yang kondusif dimana siswa merasa aman mengekspresikan pandangan mereka, dan biarkan siswa mencoba untuk berpikir tentang bagaimana benar atau salah jawabannya dan mengapa.

6. Menggunakan penilaian untuk mempelajari apa yang siswa ketahui, memantau perkembangan belajar statistik siswa, untuk mengevaluasi kemajuan dan rencana pembelajaran mereka;

Ada beberapa bentuk-bentuk penilaian alternatif yang digunakan untuk menilai siswa, antara lain, kuis, PR, ujian, atau proyek statistik sebagai bentuk penilaian otentik. Penilaian perlu disesuaikan dengan tujuan pembelajaran, dan fokus pada pemahaman ide-ide kunci dan tidak hanya pada keterampilan, prosedur jawaban. Hal ini harus dilakukan baik formatif maupun sumatif.

\section{Penelitian Terkait Penalaran Inferensial}

Berikut ini beberapa penelitian yang telah dilakukan terkait dengan penalaran inferensial:

Ben-Zvi, Gil, \& Apel (2007) mengembangkan suatu epistimologi/ kerangka kerja dari penalaran inferensial informal, yang terdiri dari aspek kognitif dan sosio kultural yang menekankan pada argumentasi. Penelitian ini dilakukan selama 2005-2007 (the Connection Project, keas 4-6) dengan fokus pada penalaran statistis siswa dan keterampilan argumentasi dengan Inquiry.

Kegiatan penelitian dan pembelajaran yang dilaksanakan dalam dua tahun pertama fokus pada penalaran tentang distribusi, variabilitas, dan bertujuan untuk mempersiapkan siswa pada pembelajaran penalaran inferensial informal untuk tahun ketiga. Penalaran inferensial informal terkait dengan sampling dan estimasi parameter dengan melakukan survey dan menggambarkan sampel acak sederhana. Hasil awal penelitian menunjukkan bahwa desain hati-hati dari lintasan pembelajaran (learning trajectory) dengan bantuan TinkerPlots berperan dalam mendukung penalaran multiplikatif, aggregate, dan mengakui peran sampel besar dan variabilitas.

Selanjutnya Prodromou (2011) menyelidiki penalaran inferensial yang muncul tentang sampel dan sampling melalui observasi pada siswa usia 13-14 tahun. Siswa membuat hubungan tentang ide statistika selama proses sampel bertumbuh dan mengakui hubungan antara ukuran sampel dan interval kepercayaan.

Makar \& Rubin (2014), meninjau penelitian terbaru dan menyelidiki isu-isu dan pertanyaan-pertanyaan terkait inferensi statistis informal pada anak-anak (usia 4-10 tahun), siswa SD, sekolah menengah (di atas 10 tahun), dan mahasiswa. Inferensi statistis informal memiliki potensi untuk mengembangkan penalaran statistis yang lebih kuat di semua tingkatan, dan pentingnya melibatkan anak-anak dalam konteks yang akrab dengan mereka untuk mengembangkan pengalaman awal informal dengan konsep statistis seperti variabilitas, ketidakpastian, dan menggunakan data sebagai bukti.

Garfield \& Ben-Zvi (2008) menggunakan SRLE untuk mengembangkan penalaran statistis dan memperoleh hasil yang lebih baik dibandingkan dengan pendekatan tradisional. Lane-Getaz (2006) melakukan penelitian berkaitan dengan penalaran inferensial formal dan mendapatkan banyak terjadi miskonsepsi terkait uji hipotesis dan interval kepercayaan.

\section{PENUTUP}

Inferensi statistis merupakan komponen sentral dalam Statistika. Untuk itu diperlukan pemahaman yang kuat tentang konten ini. Model pembelajaran SRLE dapat digunakan untuk mendukung kemampuan penalaran inferensial statistis dengan kerangka kerja dari Zieffler et al. (2008) atau Makar \& Rubin (2009). Selain itu, tentu saja meningkatkan pengetahuan guru/ dosen 
tentang penalaran inferensial. Hal ini merupakan kunci penting untuk meningkatkan kemampuan penalaran inferensial siswa/ mahasiswa.

\section{DAFTAR PUSTAKA}

American Statistical Association. (2010). Guidelines for assessment and instruction in statistics education (GAISE) college report. Retrieved from http://www.amstat.org/education/gaise.

Ben-Zvi, D., Gil, E., \& Apel, N. (2007). What is Hidden Beyond the Data? Young Students Reason and Argue about Some Wider Universe (Working Version). In D. Pratt \& J. Ainley (Eds). Reasoning about Informal Inferential Statistical Reasoning: A collection of current research studies. Proceedings of the Fifth International Research Forum on Statistical Reasoning, Thinking, and Literacy (SRTL-5).

Ben-Zvi, D., \& Aridor-Berger, K. (2012). Childrens Wonder How to Wander Between Data and Context. 12 $2^{\text {th }}$ International Congress on Mathematical Education.

Garfield, J., \& Ben-Zvi, D. (2008). Developing students' statistical reasoning: Connecting research and teaching practice. New York, NY: Springer.

Garfield, J., \& Ben-Zvi, D. (2009). Helping Students Develop Statistical Reasoning: Implementing a Statistical Reasoning Learning Environment. Teaching Statistics. 31(3), page 72-77.

Lane-Getaz, S., J. (2006). Developing an Inferential Reasoning Assessment: From a Pilot Survey to a test. AERA Paper Discussion (Roundtable). San Fransisco: CA.

Makar, K., \& Rubin, A. (2009). A framework for thinking about informal statistical inference. Statistics Education Research Journal, 8(1), 82-105. Retrieved from http://www.stat .auckland.ac.nz/ iase/serj/SERJ8(1)_M akar_Rubin.pdf.
Makar, K., \& Rubin, A. (2014). Informal statistical inference revisited. Proceedings of the Ninth International Conference on Teaching Statistics (ICOTS 9). Page 1-6.

Moore, D. S., McCabe, G. P., \& Craig, B. A. (2009). Introduction to the practice of statistics (6th ed.). New York: W. H. Freeman and Company.

Pfannkuch, M. (2006). Comparing box plot distributions: A teacher's reasoning. Statistics Education Research Journal, 5(2), 27-45. Retrieved from http://www.stat.auckland .ac.nz/ iase/serj/SERJ7(2)_ Pfannkuch.pdf.

Prodromou, T. (2011). Students' Emerging Inferential Reasoning About Samples and Sampling. Mathematics: Traditions and Practices. MERGA.

Sotos, C., Vanhoof, A., E., Van den Noortgate, S., \& Onghena, P. (2009). How confident are students in their misconceptions about hypothesis tests. Journal of Statistics Education, 17(2). Retrieved from http://www.amstat.org/publications/jse/v 17n2 /castrosotos.html

Walpole, R. E., \& Myers, R. H., (1995). IImu Peluang dan Statistika untuk Insinyur dan Ilmuwan. Edisi ke-4. Bandung: Penerbit ITB.

Weinberg, A., Wiesner, E., Pfaff, T., J. (2010). Using Informal Inferential Reasoning to Develop Formal Concepts: Analyzing an Activity. Journal of Statistics Education, 18(2), 1-24. www.amstat.org/publications/jse/v18n2/ weinberg.pdf.

Zieffler, A., Garfield, J., delmas, R., \& Reading, C. (2008). A framework to support research on informal inferential reasoning. Statistics Education Research Journal, 7(2), 40-58. Retrieved from http://www.stat.auckland.ac.nz/ iase/se ri/SERJ7(2) Zieffler.pdf. 